\title{
Conceptualizing Franchisee-based Brand Equity A Framework of the Sources and Outcomes of the Brand's Added Value for Franchisees
}

\author{
Nabil Ghantous ${ }^{1} \&$ Ferry Jaolis ${ }^{1}$ \\ ${ }^{1}$ Facultéd'Economieet de Gestion, CERGAM, Aix Marseille Université, Aix en Provence, France \\ Correspondence: Nabil Ghantous, Facultéd'Economieet de Gestion, Aix Marseille Université, 15-19 Allée \\ Claude Forbin, 13627 Aix en Provence, France. E-mail: nabil.ghantous@univ-amu.fr
}

Received: May 25, 2012

Accepted: June 7, 2012

Online Published: December 31, 2012

doi:10.5539/ibr.v6n2p112

URL: http://dx.doi.org/10.5539/ibr.v6n2p112

\begin{abstract}
Alongside business practices, the franchisor's brand is one of the two basic constituents of the franchise package that the franchisees buy into, and one of the major resources that franchisees seek when engaging in a franchise agreement. This paper addresses the value added by the brand to the franchise package from the franchisees' perspective by considering (a) the sources of this added value and (b) its impact on franchisees' intentions and behaviors. Based on previous literature on how brands generate value for consumers and firms, we first extend the concept of brand equity to franchising and propose a theoretical framework of the sources and outcomes of franchisee-based brand equity. We then explore franchisees' perspective on the brand's added value by conducting sixteen interviews with franchisees in France. The interviews combined with previous literature reveal that franchisees consider that the brand adds value directly by offering them functional, symbolic, experiential, economic and relational benefits, as well as indirectly by driving positive responses from consumers, employees and financial partners toward the branded franchised unit. Surprisingly, the symbolic benefits emerge as the strongest direct benefits. In turn, this added value attracts franchisees to enter the network, motivates their intention to continue in the franchise relationship and acts as a palliative for organizational problems encountered by franchisees. These findings indicate that franchisors should strongly integrate the brand in their value proposition in order to drive positive responses from their potential and current franchisees.
\end{abstract}

Keywords: franchising, brand equity, franchise relationship, brand benefits, franchisee attraction, retention

\section{Introduction}

Franchising has become a major driver of business development in many sectors including restaurants, hotels, retailing, hairdressing, education and B2B services. In France alone, the number of active networks grew by 42.5\% between 2007 and 2010, reaching 1477 networks with more than 58000 franchised units (French Franchising Federation, 2012). Franchising is a specific type of business venturing where "one firm (the franchisor) sells the right to market goods or services under its brand name and using its business practices to a second firm (the franchisee)" (Combs, Michael \& Castrogiovanni, 2004, p.907).This definition highlights the brand's role as a defining element of this business format and a major constituent of the franchise package alongside business practices. However, academic research on franchising has been very slow in integrating branding as a topic of investigation. Research on franchising traditionally builds on two major theories resource scarcity and agency theory - where the brand is present but does not constitute a major topic (Combs \& Ketchen, 1999; Combs et al., 2004). More recently, a new stream of research has focused on the brand as a core topic of study in franchising, with research on franchise brand management practices (Pitt, Napoli \& van der Merwe, 2003), franchisee perceptual equity (Leslie \& McNeill, 2010), franchisee-brand relationships (Nyadzayo, Matanda \& Ewing, 2011), franchisee brand piracy (Frazer, Merrilees \& Wright, 2007) and franchise branding from an organizational identity perspective (Zachary, McKenny, Short, Davis \& Wu, 2011).

Franchisors are more and more competing today with other franchisors to attract new franchisees and retain existing ones (Zachary et al., 2011). Franchisee attraction and retention is a major stake for franchisors as it guarantees the network's survival and expansion as well as it enhances the brand awareness and market share (Dantand Kaufmann, 2003; Lafontaine \& Kaufmann, 1994; Perrigot, Basset \& Cliquet, 2011). Several empirical 
studies report that the brand is one of the major factors that attract franchisees to join a network and continue in the franchise relationship (e.g. Guilloux, Gauzente, Kalika \& Dubost, 2004; Hing, 1995; Kaufmann \& Stanworth, 1995). However, none of the previous studies is dedicated to understanding the mechanisms through which the brand can positively affect franchisees' intentions and behaviors. The present research aims at addressing this gap. More precisely, the main research objective of our work is to understand from franchisees' perspective how the brand adds value to the franchise package offered by a franchisor. We do so by examining the sources of this added value. Consistently, a complementary research objective is to investigate whether this added value motivates franchisees' positive responses in the franchise relationship, mainly by attracting and retaining franchisees.

The value added by the brand to a market offering - whether a product, service or in the present case a franchise package - is known as the brand equity (Farquhar, 1989). The paper hence opens by reviewing previous literature on brand equity that explains how the brand adds value for its two main stakeholders: the customers and the firm. The brand equity construct is then extended to franchising and a framework of franchisee-based brand equity is proposed. We then present the methodology and the findings from an empirical study, based on interviews with sixteen franchisees. The paper concludes with the study's theoretical and managerial implications, including a revised version of the conceptual framework.

\section{Conceptual Background}

\subsection{Value Creation through Branding}

Beyond being mere names, logos and trademarks, the power of brands lies in their ability to deliver value to their stakeholders in addition to the value delivered by the product or service they sign. This incremental value dueto the brand is known as brand equity (Farquhar, 1989; Srivastava \& Shocker, 1991). Since the end of the 1980s, brand equity has become the focus of a wide stream of research that still thrives today both at the conceptualization and measurement level (for a recent literature review, see Christodoulides and de Chernatnoy, 2010). Beyond the common ground of considering brand equity as the value added by the brand to the offering as mentioned earlier, different conceptualizations have been presented in the literature, resulting in variations in the number and nature of brand equity's dimensions across studies.

In one of the first conceptualizations, Aaker (1991, p.15) defined brand equity as "a set of brand assets and liabilities linked to a brand, its name and symbol, that add to or subtract from the value provided by a product or service to a firm and/or to that firm's customers". This definition results in confusion due to its broad scope, including the "firm and/or [its] customers". Though it is important to stress that the brand creates value for all its stakeholders and that equity should not only be seen from the firm's perspective, it is also important to highlight that the mechanisms through which the brand adds value for the firm and for its customers are different. For instance, Aaker suggests that brand loyalty is a dimension of brand equity. Whereas brand loyalty is a source of the brand's added value for the firm, it is an outcome of the brand's added value for the customer. Hence, most research developed since Aaker (1991) addresses separately either value creation through the brand for customers - customer-based brand equity - or for the firm - firm-based brand equity (Christodoulides and de Chernatony, 2010). The distinction between both perspectives relies thus on which of the customers or the firm is the beneficiary stakeholder of the added value represented in the brand equity (Capon, Berthon, Hulbert \& Pitt, 2001; Christodoulides \& de Chernatony, 2004).

\subsubsection{Customer-based Brand Equity}

Research on customer-based brand equity has been grounded in two major paradigms. A first stream of research conceptualizes brand equity in the framework of cognitive psychology (Aaker, 1991; Berry, 2000; Keller, 1993). Building on previous research on memory structure, it considers the brand name as an information nod in consumers' memory and that this nod is directly or indirectly linked to other nods - hence the term brand associations. In this framework, Keller (1993) explains that brands create value for consumers through brand knowledge. The latter has two dimensions: brand awareness and brand associations. According to Keller, in order for the brand to add a specific value, that is to say different from the value stemming from the product or the service, the consumer must be aware of the brand. In addition, brands add value through the image they convey to consumers and that is represented in the brand associations. Hence, the more positive, strong and unique the brand associations, and the higher the brand potential in adding value for consumers (Keller, 1993). Berry (2000) adds that, though brand awareness is a necessary condition, brand image is the strongest antecedent of brand equity.

The second stream of research builds on the information economics paradigm and more specifically on information asymmetry on the markets. This asymmetry creates uncertainty and increases buyers' perceived risk, 
leading the seller to send signals to reassure the buyers (Rao, Qu \& Ruekert, 1999). For instance, companies would set high prices to convey perceptions of higher quality. In this framework, Erdem and Swait (1998) argue that the brand can act as an important signal as its name embodies the whole marketing mix of the company and encapsulates the history of consumers' interactions with the brand. Empirically, these authors have shown that when the brand acts as a credible signal, it adds value for customers since it reduces their perceived risk and information costs and enhances perceived quality (Erdem \& Swait, 1998). Despite the appeal of this second approach, the study of customer-based brand equity is predominately based on the psycho-cognitive paradigm.

\subsubsection{Firm-based Brand Equity}

Firm-based brand equity refers to the case where the company is the beneficiary of the value engendered by the brand. Three main sources of brand-based value for the firm are highlighted in the literature. The first one considers the brand as an asset of the company, contributing to the overall value of the firm and that could generate revenues if it is sold. The financial value of brands was highlighted in the $1980 \mathrm{~s}$, when brands such as Kraft were sold for a much higher price than their book value. In addition to the valuation methods developed by branding consultancies (e.g. Interbrand), academic researchers also developed financial valuation techniques such as comparing of the purchase and sale price of an acquired brand (Mahajan, Rao \& Srivastava, 1994) and calculating a residual value after discounting for all the other assets of the company (Simon \& Sullivan, 1993).

The second way brands create value for the company is through their impact on consumers' positive reactions toward the branded offering. By enhancing customers' loyalty for example, the brand participates in securing future cash-flows for the company. Similarly, another example is through the brand's potential of commending a price premium, based on consumers' willingness to pay higher prices for a brand they know, trust and like than for an unknown brand (Aaker, 1991; Ailawadi, Lehmann \& Neslin, 2003). In this perspective, firm-based brand equity is linked to customer-based brand equity, defined by Keller (1993) as "the differential effect of brand knowledge on consumer response to the marketing of the brand" (p.2). The value added (subtracted) for consumers by the brand will have a positive (negative) impact on consumers' reactions toward the branded offering, and hence add (subtract) value for the firm (Feldwick, 1996; Wood, 2000). As such, customer-based brand equity becomes a source of firm-based brand equity (Czellar \& Denis, 2002).

Finally, though most research on brand equity focuses on customers, brands can also create value for the company by commending positive reactions from other stakeholders. For instance, in one of the earliest conceptualizations of brand equity, Srivastava and Shocker (1991) consider the brand-engendered positive behaviors of channel members, in addition to those of consumers, as an important source of "strong, sustainable and differential advantage". Such enlargement of brand-equity conceptualizations to include the effects of several relevant stakeholders can be particularly important in B2B contexts and will be discussed later.

\subsection{Franchisee-based Brand Equity}

The previous paragraphs highlight that (1) brands add a specific value to markets offerings; (2) the mechanisms that explain this value adding process are closely linked to the beneficiary stakeholder (e.g. the customer or the firm); and (3) in the case of consumers, this added value drives differential consumers' responses to the branded offering's marketing. Similarly, franchisee-based brand equity (FBBE) can be defined as the value added by the brand to the franchise package, for the franchisee, and that drives the franchisee's responses to the marketing of the franchise package by the franchisor.

Two previous attempts by Nyadzayo et al. (2011) and Leslie and McNeill (2010) have recently proposed to extend equity concepts to franchising. However, these conceptualizations do not address our research objectives directly, as they do not focus on understanding how the brand drives franchisees' responses toward the franchised package through the value added by the brand. Instead, they mainly focus on franchisees' perceptions of the brand value and strength on the market and more specifically for consumers. In other words, they consider customer-based equity of the franchise brand as perceived by the franchisees. This perspective can be linked to our research objective: franchisees' perceptions of customer-based equity of the brand they are buying into will participate in explaining the value added by the brand for them. However, such perspective is restrictive at least on two levels. First, it does not consider whether or how the brand could create value directly for the franchisee, since it focuses solely on the indirect route through perceived customer-based equity. Second, even in this indirect fashion, it ignores other relevant stakeholders of the franchise relationship that could be affected by the brand.

The conceptual framework of the present research (figure 1) addresses the previous limitations. It presents an understanding of how the brand adds value for franchisees, hence driving two of their most important decisions: the choice of a franchised network and the willingness to continue the franchise relationship in the long run. To 
this effect, we build on the dual role of the franchisee in the franchised network and in his relationship to the brand. On the one hand, the franchisee is a B2B buyer in his relationship to the franchisor (Grace \& Weaven, 2011; Harmon \& Griffith, 2008) and the brand is part of the franchise package he buys (Zachary et al., 2011). On the other hand, he is an entrepreneur in his relationship to the market (Hunt, 1997) and the brand is a tool for him to attract and satisfy relevant stakeholders and more precisely the consumers.

\section{Directsources}

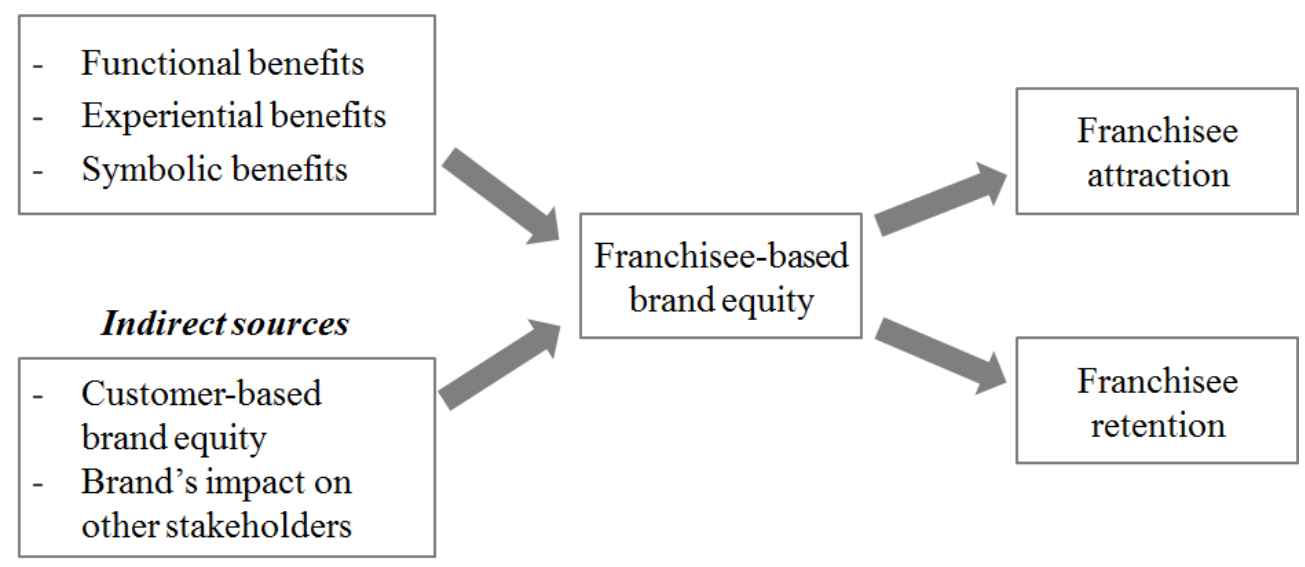

Figure 1. Sources and outcomes of franchisee-based brand equity

\subsubsection{Indirect Sources of FBBE}

Previously, we presented three routes to explain firm-based brand equity or how the brand adds value for the company: the brand as a financial asset, the brand as a trigger of consumers' positive reactions toward the market offering and as a trigger of other relevant stakeholders' positive reaction. The first of these three ways cannot explain how the brand creates value for the franchisee in his role as an entrepreneur. In the franchise relationship, the brand as an asset remains the property of the franchisor. The franchisee is granted the right to use the brand name throughout the duration of the franchise contract but does not acquire property rights on the brand (Combs et al., 2004). In other words, the brand cannot directly generate value for the franchisee as a financial asset. However, it can generate value for the franchisee indirectly, through its differential impact on consumers' perceptions and behaviors, driving positive consumer responses toward the branded franchised unit. As such, franchisees would be encouraged to enter and remain with a franchised network if they think that its brand commends high customer-based brand equity on the market (Leslie \& McNeill, 2010; Nyadzayo et al., 2011). Hence, we propose first that customer-based brand equity as perceived by the franchisee acts as an antecedent of FBBE.

In addition, the brand can generate value for the franchisee through its differential impact on other relevant stakeholders' perceptions and behaviors. The ability of the brand to offer benefits for multiple stakeholders is often considered of high importance to ensure the company's interest in and support for branding in B2B contexts (Leek \& Christodoulides, 2011). One important stakeholder group for example that the brand can attract offering thus indirectly an added value for the franchisee is the skillful personnel (Perrigot et al., 2011). Hence, franchisees would be encouraged to enter and remain with a franchised network if they think that its brand commends positive responses from relevant stakeholders on the market. We propose thus that the brand's impact on relevant stakeholders' behaviors as perceived by the franchisee will also act as an antecedent of FBBE.

\subsubsection{Direct Sources of FBBE}

One way of understanding how the brand adds value directly for the franchisee is by considering the latter in his direct relationship to the franchisor, that is to say in his role as a B2B buyer of the franchise package. Even though brand-equity research has mainly focused on consumer markets, a growing stream of research has investigated in recent years brand equity for B2B buyers, concluding that the concept is also relevant for understanding the brand's added value in B2B relationships (e.g. Bendixen, Bukasa \& Abratt, 2004; Jensen \& Klastrup, 2008; Kuhn, Alpert \& Pope, 2008; Lindgreen, Wynstra \& Farrelly, 2010; Zaichkowsky, Parlee \& Hill, 2010). On the conceptual level, several studies carried out in this stream transpose tools and frameworks of 
studying and evaluating brand equity used on consumer markets (Leek \& Christodoulides, 2011, 2012). Kuhn et al. (2008) tested the applicability of Keller's (2001) customer-based brand equity pyramid to B2B customers, showing that this framework is applicable under certain modifications. Whereas Keller's (1993) original work distinguishes between the sources of brand equity (i.e. brand knowledge) and its consequences (i.e. consumer's differential responses to the branded offering), the CBBE pyramid describes the four steps that companies should follow in order to build strong brands. Keller's original framework (1993) seems hence more adequate to our study of how the franchise brand adds value for a specific kind of buyers - the franchisees - and how in turn this added value drives franchisees' positive reactions, in this case franchise choice and relationship continuation.

According to Keller (1993), the brand's added value and its impact on customers' responses are driven by brand awareness and associations. Keller distinguishes different types of brand associations based on their abstraction level in consumers' minds, ranging from attributes (the least abstract), to benefits, and finally to attitudes (the most abstracts). Due to their intermediate position on abstraction, benefits offer interesting insights to how the brand adds value for stakeholders, since they combine a high level of uniqueness, durability and accessibility in stakeholders' memory (Keller, 1993). Consistent with earlier research (Park, Jaworski \& MacInnis, 1987), Keller distinguishes three categories of brand benefits that could all be transposed to the franchising context.

The first category relates to functional benefits, rooted in the product or service attributes. It mainly refers to the latters' problem-solving capacity. Functional benefits mirror previous research in B2B on the importance of product features and their performance in the brand evaluation (Kuhn et al., 2008). The second category refers to experiential benefits resulting from the sensory stimulation of consumers' by the brand. Franchisors place a lot of emphasis on designing brand logos and other elements of sensory identity as well as the franchised units' servicescape in order to enhance the networks' visibility and consumers' experience. Research in services marketing has established that these sensory elements do not only affect customers' perceptions and behaviors, but also those of the employees working in the service unit (Bitner, 1992). As small entrepreneurs, most franchisees tend to actively participate in the management of their business and the delivery of the service, being thus highly present in their franchised units and in contact with the products and servicescape. Hence, the brand could also convey experiential benefits for the franchisees. Finally, the third category refers to symbolic benefits associated with the brand, linked for example to self-expression. The importance of these benefits in B2B branding is subject to controversy. Whereas some findings stress the rational aspect of B2B buyers, excluding the role of symbolic imagery (Kuhn et al., 2008), other studies report the role of emotional aspects of B2B brands for the buyers (Leek \& Christodoulides, 2012; Lynch \& de Chernatony, 2004). Franchisees are not standard B2B buyers. They are often small entrepreneurs who enter a franchised network to develop a personal as well as an economic project. The values the brand conveys through its identity could trigger a self-expressive value for franchisees.

\section{Methodology}

An empirical study was designed in order to further investigate (1) the sources of value added by the brand for franchisees and (2) whether this added value drives franchisees' behaviors, mainly at the level of the choice of a franchise network and the continuation of the franchise relationship. Qualitative research was deemed the most appropriate methodology, given the lack of literature on branding's role and impact in the franchise relationship and the exploratory nature of our research.

We conducted in-depth semi-structured interviews with sixteen franchisees in the region of Aix-en-Provence and Marseille in France. The informants were chosen through purposeful sampling, with the aim of selecting franchisees from different sectors in order to cover a broad range of views, but at the same time by setting two criteria to avoid extreme heterogeneity of informants that could be detrimental to the understanding and interpretation of collected material. The first criterion was to select only franchisees operating on a $\mathrm{B} 2 \mathrm{C}$ market, as we suspected that the brand's role and management at the level of the franchised unit might be significantly different between B2B and B2C contexts. The second criterion was to select franchisees of brands that exist from several years and have developed a minimum level of awareness and equity on their respective markets. This second criterion was set as, in the case of recently established brands with little awareness, franchisees behaviors under investigation in the present study and most precisely the choice of a franchise network would probably rely much more on constituents of the franchise package other than the brand (e.g. product, technical assistance, royalties, etc.). We are conscious that these two restrictions limit in return the generalizability of our results. However, given the exploratory nature of the research and the breadth of the franchise context, such restrictions seem necessary to avoid contextual bias in the interpretation of our results. 
The interviewing process was stopped when saturation level was reached. $56 \%$ of the informants operated service franchised units (e.g. restaurant, hairdresser, real estate agency), while the remaining $44 \%$ operated retail franchised units (e.g. shoe store, organic food retailer). The participants and franchised sectors are presented in table 1. Face-to-face interviews were conducted on the franchisees' work setting. They lasted between 0 and 75 minutes, and each interview was recorded and later transcribed.

The mains themes in the interview guide were the factors taken into account by the franchisee in his choice of the franchise network, the role and importance of the brand in franchising, the brand's appeal for franchisees and the benefits they can reap with the brand, franchisees' perceptions of the franchise brand, the brand's impact on franchisees' behaviors and the reasons for continuing in the franchise relation. Transcripts were later examined using content analysis (Krippendorff, 2004) with two kinds of codes. First, a priori codes were derived from previous literature to cover the different themes portrayed in the conceptual framework (figure 1). Second, given the exploratory nature of the study, additional codes were derived from the interviews with the aim of covering supplementary themes that were not revealed by the literature review.

Table 1. List of the interviewees and their sector of activity

\begin{tabular}{ll}
\hline Interviewee & Sector \\
\hline MB & Retail: second hand products \\
TN & Retail: proximity store \\
BL & Retail: organic food \\
BA & Retail: chocolate store \\
JM & Retail: shoe store \\
LQ & Retail: luxury wine \\
NB & Retail: home decoration \\
PMP & Retail and service: printing cartridge \\
AI & Services: pizza restaurant \\
SA & Services: hairdresser, beauty salon \\
SM & Services: hairdresser \\
VC & Services: hair dresser \\
JA & Services: real estate agent \\
KB & Services: hairdresser \\
PE & Services:café \\
VD & Services: restaurant \\
\hline
\end{tabular}

\section{Main Findings and Discussion}

\subsection{Direct Sources of FBBE}

As expected in our initial framework, the interviews reveal that the brand adds value directly for franchisees through brand awareness and by offering them functional, experiential and symbolic benefits (Keller, 1993; Park et al., 1986). The interviews also reveal two additional types of direct benefits: economic and relational benefits.

Brand awareness was very noticeable in the interviews as an important factor for franchisees, especially when discussing the phase of choice before entering the network. In many sectors, potential franchisees have a choice between several competing franchisors, whose offerings are sometimes difficult to differentiate on the functional level of the service concept or the franchising package. In addition, many entrepreneurs in search for a franchised business might have little or no experience in this domain. On consumer markets, consumers with little expertise about the product use the brand awareness to form their consideration set and even as a driver of their final choice (Keller, 1993). This seems also the case of some of the interviewed franchisees. For instance, franchisee LQ (luxury wine retailer) describes his choice of a franchise as comprising two phases: first, he chose the business sector (luxury wine retailing) and the business format (franchising), then he "searched his memory" for what brands operate in this framework. In other words, brand recall - one of the two components of brand awareness, alongside brand recognition - acted as a heuristic to simplify the franchisee's choice, saving him time and effort. For other franchisees (e.g. VC, hairdresser), brand awareness adds value by reducing the risk associated with being an entrepreneur, since it augments their chances of success. In this particular case, the franchisee felt secure as part of the branded network, mirroring the old motto in franchising: "being in business for yourself, not by yourself". 
Amongst brand associations, symbolic benefits are, surprisingly, the most recurrent and salient benefits in franchisees' discourse. This is in contradiction with both intuition and previous results (e.g. Kuhn et al., 2008) that emphasize mainly the rational aspect of B2B buyers' decision making process. The interviews highlight several drivers of symbolic benefits. First, franchisees use the brand and its image as a self-expressive tool, by stressing the importance of self-congruity with their franchise brand. Self-congruity has been studied extensively in consumer behavior, mainly since the seminal work of Sirgy (1982). It reflects the extent to which consumers' representations of the brand match their own self-image. As such, it is possible to define different kinds of self-congruity according to the type of self-image to which the brand image is being compared (e.g. actual vs. ideal self-congruity). Many franchisees expressed the importance of the brand for them as a way of expressing their actual self. For instance, franchisees JM (shoe store) and BA (chocolate store) stated that they "recognize [themselves] in the product and the concept". Another statement of actual self-congruity comes from franchisee KB (hairdresser) who stated: "I find that it [i.e. the brand] resembles us a lot: we are beautiful, we are classy, we are a woman... we are [the brand name]!". The brand also acts as a source of inspiration for franchisees. Its image represents what they aspire to and allows them to express their ideal self. For instance, franchisee KB extensively explained to us the history of the hairdressing brand and how it was closely linked at the time of its launching to French icon Brigitte Bardot. As such, being part of this network and, more importantly, being associated with this brand, was for franchisee KB a way of reaching for an ideal-self that could only be attained through this association.

Second, the interviews also reveal the importance for the franchisees of being associated with a brand with a strong personality. This was particularly salient in the case of networks where the product or service itself had a high symbolic or self-expressive value. For instance, franchisees JM (shoe store), KB and SM (hairdresser) all emphasized that their brands reflected images of beauty, glamour, class, and luxury. This was often accompanied by country stereotypes, especially when the brand name had a foreign consonance. Third, the brand also delivers symbolic benefits when its identity is strongly rooted in values such as social responsibility, ecological concern and sustainable development. Some franchisees like BL (organic food retailer) expressed that the brand values are at least equally important for them as the brand financial and economic value. For this franchisee, the monetary value the brand adds to his business by attracting customers would not have been sufficient to enter the franchise network if the brand did not allow him to "help people eat more healthy food". By combining value and values, the brand offers the franchisee "a double pleasure".

Finally, another symbolic benefit that emerged from the interviews was the fact of being associated with a leading brand. Franchisee SA (hairdresser) expressed the importance of the fact that the brand was the leader in its sector and recognized by all as such. This was paramount for the franchisee's choice of the network, as he wants to be associated with "the best". Likewise, franchisee AI (pizza restaurant) insisted in the interview that the brand, though not the market leader, is the French leader on the market (the market leader being an American competitor chain). In both cases, the fact of being associated with a "leader" was considered as a source of pleasure and pride for the franchisee.

Functional benefits delivered by the brand are linked to both marketing and human resources activities usually carried out by the entrepreneur, but that were in this case carried out by the network headquarter teams. On the marketing side, the brand offers benefits for franchisees as it stands for a solid and well thought of concept, tailored to meet target customers' needs and desires. In addition, the brand also carries out national advertising and communication campaigns. The latter are seen as very important by the interviewees as such campaigns enhance brand awareness and build strong brand image, and also because franchisees do not have the required abilities to develop such campaigns. A third marketing advantage pointed out by franchisee JM (shoe store) is that brands place a lot of emphasis on product quality and innovation in order to maintain their image and market share. From the franchisee's perspective, being associated with a brand is hence a way to benefit from these innovations. Brands also offer human resources advantages, especially in service industries. Several franchisees, including JA (real estate agency) and SM (hairdresser), pointed out that an important advantage of being part of a network with a strong brand is that such networks place much emphasis on training franchisees' frontline employees. This HR advantage echoes the importance of frontline employees in services: not only do they deliver the brand promise during the service encounter, but they also embody the brand in consumers' eyes. As such, frontline employees are considered as services brand builders (de Chernatnoy \& Segal-Horn, 2003).

Experiential benefits were much less salient in the interviews than the two previous categories. The franchisees mentioned two types of experiential benefits. The first ones are linked to the presentation, shape, taste and packaging of the tangible product that is sold in the franchised unit. This was more important in retailing franchises than in services franchises. The other experiential benefits are linked to the sensory experience of the 
franchisee with the servicescape of the franchised unit, including the colors, themes, layouts and other ambient conditions. In addition to mentioning such specific elements of the service environment, some franchisees emphasized their holistic experience of the place:

“At [brand name], it's as if it were a castle! It is not your house; it's a castle, a palace, a luxurious manor, so it's even better than one's own home" (KB, hairdresser).

In addition to the previous three categories of benefits, franchisees also pointed out that being part of a network with a strong brand offers them economic benefits. More specifically, several franchisees noticed that building a strong brand is a heavy and resource-consuming task. Three types of resources were specifically mentioned when we asked the franchisees to elaborate on this idea: financial investment for brand building; internal competencies needed to grow and manage the brand, mainly in the marketing area; and time, as strong brands might take many years to develop. These categories of resources are closely linked to the aforementioned functional benefits. However, franchisees seem to distinguish between both types of benefits when discussing what they get from being in a branded network. More specifically, functional benefits refer to the access they have to resources as part of the branded network, while economic benefits refer to the possibility of obtaining the functional benefits at a lower price - in the present case the royalties - and in better conditions than what they could get as single entrepreneurs.

Finally, the interviews also reveal relational benefits. Franchisees expressed the ideas of "belongingness", "community" and even "family" when describing the franchise brand. This was first obvious through the personal ties the franchisee develops with other franchisees of the same network. In this framework, franchisee JA (real estate agency) highlighted the importance of bonding with the other members of the network on the one hand, and on the other hand the fact that such relationships would not exist or at least would not be the same without the brand. In this specific case, through its deep identity and its shared values, the brand acts as the glue for the community. Another franchisee (SM, hairdresser) reported that his franchised unit was chosen as a training center for other franchisees. As such, not only was he responsible of the training, but of transmitting the brand's desired image and value to the other franchisees. Hence, the brand played as a relationship fulcrum between him and his peers. Several franchisees expressed their belongingness not to a community of franchisees of the same network, but to a larger community of individuals sharing the same lifestyle and passions that are portrayed in the brand concept and/or positioning (e.g. LQ, luxury wine and food retailing). Finally, some franchisees also underlined that the brand plays a role in their relationship with the franchisor. Franchisees expressed mainly the theme of "trust", with the idea that the franchisor was entrusting them with the brand - one of his most valuable resources. This is for example particularly salient in the case of the hairdresser whose franchised unit was chosen as a training center, and who felt hence entrusted with the brand by his franchisor.

These relational benefits echo and supplement the results of Nyadzayo et al. (2011) who found "relationship value" to be one of the three dimensions of FBBE. However, the dimension they describe is solely focused on the franchisee-franchisor relationship, whereas our findings underline the relational role of the brand at a much broader level: toward the franchisor, other franchisees and the brand community at large.

\subsection{Indirect Sources of FBBE}

The brand also offers indirect benefits for the franchisees, based on their perceptions of its ability to drive positive reactions toward the branded franchised unit from relevant stakeholders. The strongest of both direct and indirect sources of brand-added value for franchisees is the brand's impact on customers. More specifically, the major source of FBBE seems to be franchisees' perceptions of customer-based brand equity. Consistent with Keller's (1993) work on customer-based brand equity, the franchisees emphasized the importance of customers' brand awareness and image - the two components of brand knowledge - as well as the differential effect of the brand on customers' behaviors toward the franchised unit. Customers' brand awareness was considered as paramount by several franchisees who underlined the role of having a well-known brand in attracting new customers, reducing consumers' perceived risk and enhancing the unit's turnover. Considering brand image, franchisees (e.g. VC, hairdresser; TN, grocery shop; LQ, luxury wine retailer) also highlighted the role of the three categories of benefits for consumers - i.e. functional, experiential and symbolic - as well as the role of brand attitude. These associations have the same positive outcomes on consumers' behaviors according to the franchisees as brand awareness. However, awareness is portrayed as playing a more important role than image in attracting new customers. This is consistent with previous research on customer-based brand equity, were image is considered to have a stronger effect than awareness except in the case of new customers (Berry, 2000). 
Beyond the brands' role in driving positive consumer responses toward the branded franchised unit, the interviews also highlight the brands' importance for franchisees through their perceptions of the brand's impact on other relevant stakeholders' positive responses. Two stakeholder groups are particularly salient in the interviews. First, the brand is considered by franchisees as a tool to attract the "best" and "most skilled" employees toward the franchised unit. This is consistent with recent research on employee-based brand equity (e.g. King \& Grace, 2009) as well as on employer branding that emphasize how the company can and should brand itself to appeal to potential employees (Backhaus \& Tikoo, 2004). Second, two franchisees (BL, organic food retailer; LQ, luxury wine retailer) also pointed out that the brand, through its awareness and image, can also drive positive reactions from financial partners and more specifically from banks. Precisely, both franchisees stated that the brand can reduce bankers' perceived risk when evaluating the franchisee's business project in case of a loan for example. The brand acts thus as a risk reducer, enhancing the bankers' trust in franchisees' potential of success and in turn of paying back their loans. It is noteworthy however that the brand's effect on positive behaviors from employees and bankers, though source of added value for the franchisees, is more considered by the latter as a "positive side-effect" than as a core sought after benefit.

\subsection{The Impact of FBBE in the Franchise Relationship}

The brand added value for the franchisee, based on the previous direct and indirect benefits, has an impact on various aspects of the franchise relationship, i.e. the relationship of the franchisee to the franchisor.

Consistent with the framework of figure 1, the brand plays an important role in franchisees' decision to join a franchised network. When asked about the reasons of selecting a specific network, the brand was often spontaneously cited by the interviewees, sometimes even as a top-of-mind reason (e.g. franchisee LQ, luxury wine retailer). For most of the interviewees, the brand represents a strategic resource that is important enough to drive their decision to joina network. This is consistent with the extensive use of resource-exchange theory in the franchising literature to explain how the partners of the franchise start a business relationship in order to access each other's valuable and scarce resources. In this perspective, the franchisor's brand is usually considered among the main resources driving franchisees' willingness to go into the franchising agreement (e.g. Combs \& Ketchen, 1999). However, it is noteworthy that the functional and economic benefits presented in paragraph 4.1. supplement the traditional perspective on the role of the brand as a strategic resource sought by the franchisee. In fact, our findings add a nuance by highlighting the role of the brand as a somehow "higher order resource": franchisees' are motivated by having access to both the brand as a resource in its own right as well as to the resources needed to develop and manage the brand.

The brand also acts as an important driver of franchisees' willingness to remain in the network. This willingness is motivated in the interview both by the initially sought benefits - mainly symbolic, functional and economic as well as those revealed to the franchisee during later stages of the franchise relationship - mainly experiential and relational benefits.

"Why we stay in the network? Well because we love this brand, because we identify with this brand" (franchisee $\mathrm{KB}$, hairdresser)

"We all need to work together, and for me the brand brings me that. Even if I am competent, I am still more competent thanks to the brand, and that is what I am after. I know many people, many fellow colleagues, and all this through the brand, so I cannot picture myself today in the real estate business with another brand" (JM, real estate agency)

Finally, in addition to the brand's positive impact on franchisees' attraction and retention as posited in our initial framework, the interviews reveal an additional positive role of the brand as a palliative to internal problems. For instance, franchisee NB (chocolate store) describes the role of the brand during an organizational change period. Specifically, the regional manager of the network with who the franchisee was regularly in contact and who initially "recruited" her, was replaced by another manager. Hence, during the first period, the franchisee had to deal with a new manager. The brand played here as an anxiety and risk reducer during the change period. In another context, franchisee KB (hairdresser) described internal conflicts in the organization and a deteriorated organizational climate during an extended period of time. However, this did not drive this franchisee out of the network as "internal problems cannot even taint [the brand's] reputation".

\section{Conclusions}

\subsection{Theoretical Implications}

The present research adds insights to the emerging stream of research on brands' role and management in franchising. A first noteworthy result from the empirical study refers to franchisees' views on the nature of the 
franchise brand. Consistent with previous research on branding in B2B contexts (e.g. Kuhn et al., 2008), franchisees conceive the franchise brand mainly at the corporate level and not at the product level. This seems equally true for services franchises - with a highly intangible core offering - as well as for retailing franchises with tangible products, sometimes carrying a different brand name than the franchised unit. It is also noteworthy that franchisees adopted a large view when discussing the brand and branding, as can be seen in the three following points. First, most of the interviewees do not consider the brand as a mere name or identifier. Consistent with the psycho-cognitive paradigm, they emphasize the network of associations linked to the brand and the value-adding role of these associations to them and to their stakeholders. Second, the brand is presented in franchisees' discourse as a bundle of characteristics that, similarly to Aaker's (1996) vision of the brand, are reflected in the brand as a name, a product, an organization and a person. Third, franchisees hold a holistic view of the branding process. Beyond the narrow prism of advertising and communication, they describe branding as encompassing other marketing, HR, logistics and R\&D activities necessary to grow the brand.

The empirical study also offers insights on the two research questions, by corroborating the different themes in our initial framework (figure 1) and by supplementing them with new insights. The revised conceptual framework of FBBE is presented in figure 2.Franchisees' discourse highlights the existence of a myriad of both direct and indirect sources of FBBE that go beyond the three dimensional model of FBBE developed by Nyadzayo et al. (2011). The direct sources build to a large extent on Keller's (1993) and Park et al. (1986) typology of brand benefits. However, as in the case of Keller's (2001) CBBE pyramid that needs adjustments for B2B buyers (Kuhn et al., 2008), the initial benefits' typology is altered in the franchising context. Two new types of benefits emerge in the revised framework. First, economic benefits - linked to resources saving - mirror the dual role of the franchisee who is not a "regular" customer but an entrepreneur seeking his best economic interest when buying into a franchise package. Second, the study also reveals the importance of relational benefits. The role of the brand as a relationship fulcrum has been pointed out on consumers' markets on multiple occasions, both in research on services branding (Dall'Olmo Riley \& de Chernatony, 2000) and on brand communities (Muniz \& O'Guinn, 2001). In franchising, the franchisor develops a network of franchisees around the brand. As in consumers' brand communities, relationships inside the network are driven by franchisees association with the common brand. The present study shows that the brand acts as glue for the network cohesion.

\section{Direct sources}

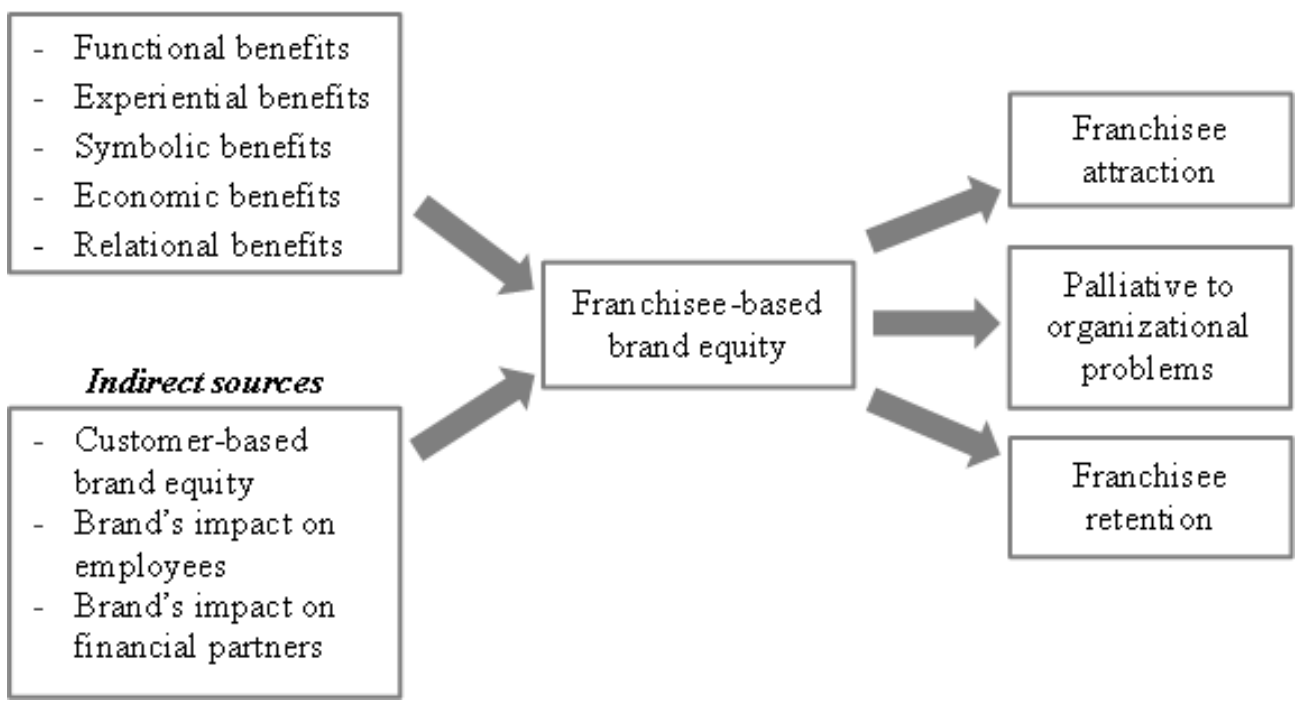

Figure 2. Revised framework of the sources and outcomes of franchisee-based brand equity

The role of symbolic benefits also emerges as paramount. Franchisees experience a wide variety of symbolic benefits, ranging from the static description of the brand through personality traits and country stereotypes to the more relationally oriented self-expressive function of the brand. This strong emphasis on symbolic imagery and benefits contrasts with the less assertive and more controversial results on the role of symbolic and emotional qualities in business contexts (Bendixen et al., 2004; Kuhn et al., 2008; Leek \& Christodoulides, 2012; Mudambi, Doyle \& Wong, 1997). 
The empirical study also allows revising and adding more precision to the indirect sources of FBBE in the initial framework. As in other B2B contexts (Leek \& Christodoulides, 2011), the franchise brand acts as a relationship facilitator not only between the seller (i.e. the franchisor) and the buyer (i.e. the franchisee), but also with different other stakeholders. Consumers are by far the most important stakeholder of the franchise brand in franchisees' eyes. Consistent with previous studies (Leslie \& McNeill, 2010; Nyadzayo et al., 2011), franchisees' perceptions and anticipations of customer-based brand equity of the franchisor are the strongest brand-related driver of franchisees' intentions to enter and remain in a network. Franchisees also reap side-benefits through the brand's positive impact on two other stakeholders: employees and financial partners. However, these side-benefits are not sought after by the franchisee before entering the network. Moreover, in the later stages of the franchise relationship, these benefits remain as side-benefits and do not seem to compensate if other, more central benefits are missing.

The revised framework in figure 2 also integrates an additional outcome of the brand's impact on franchisees' behavior. As expected in the initial framework, the brand is considered by the franchisees as a valuable resource driving their decisions to enter and remain in the network. In addition to these positive effects in normal times, the brand also plays a positive role during crisis times. Franchisees' attitudes toward the brand and the relationship they develop with it can become strong and enduring enough not to dissolve when internal problems or change periods occur. Even more important is the fact that the brand plays as a palliative and a positive change agent in these times, reducing franchisees' perceived risk and maintaining their trust in the franchise relationship.

Finally, a noteworthy point that should be further investigated in future research is the role of time. Specifically, changes seem to occur in the different components of the framework as well as in their importance for the franchise relationship. Though the research design does not allow extensively investigating these questions, four observations can be made based on the interviews. First, the importance of the brand in franchisees' decision process and behaviors becomes stronger with time. At the beginning of the relationship, the brand is one important element of the franchise package, but other elements pertaining to functional aspects of the franchise agreement (e.g. contract terms, royalties) can be at least equally important. Several franchisees underlined that the brand becomes more important to them with time. This is mainly due to the fact that they become much more aware of the direct and indirect benefits delivered by the brand. Second, the relative importance of brand awareness in comparison to brand associations also evolves with time. At the beginning of the relationship, many franchisees have little experience with the brand they buy into. Their brand perceptions are predominately based on advertising instead of direct experience. As such, brand awareness plays the major role in reducing choice complexity and associated risk.

Third, the five categories of direct benefits are not as relevant to franchisees at all stages of the franchise relationship. Functional and symbolic benefits are often the main drivers at the pre-entry stage. Economic benefits are sought after from the start, but reveal to be much more complex and important once the franchisee is in the network and sees by himself - and with the help of internal communication - the necessary resources for brand development and management. Experiential and relational benefits take more time to develop. Fourth, the indirect benefits of the brand through various stakeholders are very heterogeneous. Franchisees put much emphasis from the start on the brand's ability to drive positive consumer responses. However, some franchisees pointed out that the brand becomes even more important for them after they receive customers' feedback and feel customers' attachment to the brand. Conversely, the brand's role in facilitating the franchisee's relationships with potential employees and financial institutions is most often discovered by the franchisee after he becomes part of the network. Based on all these elements, we propose to integrate time as a moderator of the importance of the components of the framework and their relationships. However, given the lack of information on this topic from the interviews, such moderating role should be more carefully investigated in the future.

\subsection{Managerial Implications}

By confirming the brand's role as a value adding device and a trigger of franchisees' positive responses in the franchise relationship, the present research highlights the brand potential both as a resource for attracting franchisees and a tool for managing the franchise relationship. Whereas many brands are traditionally built to target and appeal to the end consumers in an outside-in approach, our findings add to the growing literature on the importance of internal stakeholders of the brand and the need to implement a balanced approach to brand building that addresses the needs and concerns of both internal and external audiences (e.g. de Chernatony \& Harris, 2000; Ind \& Bjerke, 2007). Given the corporate nature of the brand in franchising, it is important that the franchisor and the franchisees develop a corporate culture that not only is supportive of the brand, but is also aligned with its image and vision (Hatch \& Schultz, 2003). 
Moreover, given the multifaceted nature of the brand in franchisees' eyes, franchisors' value proposition for their brand should be devised in a large way to portray the numerous brand benefits for franchisees. In the application of resource-exchange theory to franchising, the brand is considered as a scarce and valuable resource that the franchisee - a rational economic agent - seeks. The importance of symbolic benefits and more precisely of self-congruity offers an alternative view of the brand's role. It also portrays the franchisee no longer as a solely rational economic agent but as an individual entrepreneur who is willing to invest his limited resources to build his "own" business that reflects his actual or ideal-self. Franchisors should hence strive to develop a clear brand personality and to use the latter not only as an external communication tool toward end consumers but also toward potential and current franchisees. Self-congruity has been shown to have positive impacts on customers' (e.g. Kressmann et al., 2006) and employees' (e.g. Kristof-Brown, Zimmerman \& Johnson, 2005) behaviors and commitment. Future research is thus needed to investigate the role and impact of franchisees' self-congruity with the franchise brand. A positive role should encourage franchisors to use brand personality as a communication tool toward potential franchisees as well as a decision making element when selecting future franchisees.

With time, franchisees seem to become aware of several direct and indirect brand benefits that add value to the franchise relationship. This is the case of the direct experiential and relational benefits and of the indirect benefits through the wide stakeholders' network. As a source of added value for franchisees, these brand associations should be activated by the franchisor even at earlier stages of the franchise relationship. For instance, most of the communication done by franchisors toward franchisees in the specialized press in France focuses mostly on the product/service concept and the technical details of the franchise agreement. Reference to the brand's impact on consumers is more implicit and is often suggested by stating the network's market share. Such communications could be enlarged to portray the other brand benefits such as the ease of recruiting qualified staff or more details on customers' loyalty.

\section{References}

Aaker, D. (1991). Managing Brand Equity. New York: The Free Press.

Aaker, D. (1996). Building Strong Brands. New York: The Free Press.

Ailawadi, K. L., Lehmann, D. R., \& Neslin, S. A. (2003). Revenue premium as an outcome measure of brand equity. Journal of Marketing, 67(4), 1-17. http://dx.doi.org/10.1509/jmkg.67.4.1.18688

Backhaus, K., \& Tikoo, S. (2004). Conceptualizing and researching employer branding. Career Development International, 9(5), 501-517. http://dx.doi.org/10.1108/13620430410550754

Bendixen, M., Bukasa, K. A., \& Abratt, R. (2004). Brand equity in the business-to-business market. Industrial Marketing Management, 33, 371-380. http://dx.doi.org/10.1016/j.indmarman.2003.10.001

Berry, L. (2000). Cultivating service brand equity. Journal of the Academy of Marketing Science, 28(1), 128-137. http://dx.doi.org/10.1177/0092070300281012

Bitner, M. J. (1992). Servicescapes: the impact of physical surroundings on customers and employees. Journal of Marketing, 56, 57-71. http://dx.doi.org/10.2307/1252042

Capon, N., Berthon, J. P., Hulbert, J., \& Pitt, L. (2001). Brand custodianship: a new primer for senior managers. European Management Journal, 19(3), 215-27. http://dx.doi.org/10.1016/S0263-2373(01)00019-6

Christodoulides, G., \& de Chernatony, L. (2004). Dimensionalising on- and offline brands' composite equity. Journal of Product \& Brand Management, 13(3), 168-179. http://dx.doi.org/10.1108/10610420410538069

Christodoulides, G., \& de Chernatony, L. (2010). Consumer-based brand equity conceptualisation and measurement. A literature review. International Journal of Market Research, 52(1), 43-66. http://dx.doi.org/10.2501/S1470785310201053

Combs, J., \& Ketchen, D. (1999). Explaining inter-firm cooperation and performance: Toward a reconciliation of predictions from the resource-based view and organizational economics. Strategic Management Journal, 20(9), 867-888. http://dx.doi.org/10.1002/(SICI)1097-0266(199909)20:9<867::AID-SMJ55>3.0.CO;2-6

Combs, J., Michael, S., \& Castrogiovanni, G. (2004). Franchising: a review and avenues to greater theoretical diversity. Journal of Management, 30(6), 907-931. http://dx.doi.org/10.1016/j.jm.2004.06.006

Czellar, S., \& Denis, J. E. (2002). Un modèle intégrateur du capital client de la marque: une perspective psycho-cognitive. Recherche et Applications en Marketing, 17(1), 43-56.

Dall'Olmo Riley, F., \& de Chernatony, L. (2000). The service brand as relationships builder. British Journal of Management, 11(2), 137-50. http://dx.doi.org/10.1111/1467-8551.t01-1-00156 
Dant, R. P., \& Kaufmann, P. J. (2003). Structural and strategic dynamics in franchising. Journal of Retailing, 79, 63-75. http://dx.doi.org/10.1016/S0022-4359(03)00011-3

De Chernatony, L., \& Harris, F. (2000). Developing corporate brands through considering internal and external stakeholders. Corporate Reputation Review, 3, 268-274. http://dx.doi.org/10.1057/palgrave.crr.1540119

De Chernatony, L., \& Segal-Horn, S. (2003). The criteria for successful services brands. European Journal of Marketing, 37(7/8), 1095-1118. http://dx.doi.org/10.1108/03090560310477681

Erdem, T., \& Swait, J. (1998). Brand Equity as a Signaling Phenomenon. Journal of Consumer Psychology, 7(2), 131-157. http://dx.doi.org/10.1108/03090560310477681

Farquhar, P. (1989). Managing brand equity. Journal of Advertising Research, 30(4), RC7-RC12.

Feldwick, P. (1996). What is brand equity anyway, and how do you measure it? Journal of the Market Research Society, 38(2), 85-104.

Frazer, L., Merrilees, B., \& Wright, O. (2007). Power and control in the franchise network: an investigation of ex-franchisees and brand piracy. Journal of Marketing Management, 23(9/10), 1037-1054. http://dx.doi.org/10.1362/026725707X250458

French Franchising Federation. (2012). Enquette Annuelle de la Franchise. Retrieved June 15, 2012, from http://www.franchise-fff.com.

Grace, D., \& Weaven, S. (2011). An Empirical Analysis of Franchisee Value-in-Use, Investment Risk and Relational Satisfaction. Journal of Retailing, 87, 366-380. http://dx.doi.org/10.1016/j.jretai.2010.06.001

Guilloux, V., Gauzente, C., Kalika, M., \& Dubost, N. (2004). How France's potential franchisees reach their decisions: a comparison with franchisers' perceptions. Journal of Small Business Management, 42(2), 218-224. http://dx.doi.org/10.1111/j.1540-627X.2004.00107.x

Harmon, T. R., \& Griffiths, M. A. (2008). Franchisee perceived relationship value. Journal of Business \& Industrial Marketing, 23(4), 256-263. http://dx.doi.org/10.1108/08858620810865834

Hatch, M. J., \& Schultz, M. (2003). Bringing the corporation into corporate branding. European Journal of Marketing, 37(7/8), 1041-1064. http://dx.doi.org/10.1108/03090560310477654

Hing, N. (1995). Franchisee satisfaction: Contributors and consequences. Journal of Small Business Management, 33(2), 12-25.

Hunt, S. D. (1997). Franchising: promises, problems, prospects. Journal of Retailing, 53(3), 71-84.

Ind, N., \& Bjerke, R. (2007). Branding Governance: A Participatory Approach to the Brand Building Process. Chichester: J. Wiley \& Sons.

Jensen, M. B., \& Klastrup, K. (2008). Toward a B2B customer-based brand equity model. Journal of Targeting, Measurement and Analysis for Marketing, 16(2), 122-128. http://dx.doi.org/10.1057/jt.2008.4

Kaufmann, P. J., \& Stanworth, J. (1995). The decision to purchase a franchise: a study of prospective franchisees. Journal of Small Business Management, 33(4), 22-33.

Keller, K. L. (1993). Conceptualizing, measuring, and managing customer-based brand equity. Journal of Marketing, 57(1), 1-22. http://dx.doi.org/10.2307/1252054

Keller, K. L. (2001). Building customer-based brand equity: A blueprint for creating strong brands. Working Paper $N^{\circ}$ 01-107, Marketing Science Institute.

King, C., \& Grace, D. (2009). Employee Based Brand Equity: a third perspective. Services Marketing Quarterly, 30(2), 122-147. http://dx.doi.org/10.1080/15332960802619082

Kressmann, F., Sirgy, J., Herrmann, A., Huber, F., Huber, S., \& Lee, D. J. (2006). Direct and indirect effects of self-image congruence on brand loyalty. Journal of Business Research, 59, 955-964. http://dx.doi.org/10.1016/j.jbusres.2006.06.001

Krippendorff, K. (2004). Content Analysis: An Introduction to Its Methodology. California: Sage Publication.

Kristof-Brown, A., Zimmerman, R., \& Johnson, E. (2005). Consequences of individuals' fit at work: a meta-analysis of person-job, person-organization, person-group and person-supervisor fit. Personnel Psychology, 58(2), 281-342. http://dx.doi.org/10.1111/j.1744-6570.2005.00672.x 
Kuhn, K. A. L., Alpert, F., \& Pope, N. K. L. (2008). An application of Keller's brand equity model in a B2B context. Qualitative Market Research: An International Journal, 11(1), 40-58. http://dx.doi.org/10.1108/13522750810845540

Lafontaine, F., \& Kaufmann, P. J. (1994). The evolution of ownership patterns in franchise systems. Journal of Retailing, 70(2), 97-113. http://dx.doi.org/10.1016/0022-4359(94)90010-8

Leek, S., \& Christodoulides, G. (2011). A literature review and future agenda for B2B branding: Challenges of branding in a B2B context. Industrial Marketing Management, 40, 830-837. http://dx.doi.org/10.1016/j.indmarman.2011.06.006

Leek, S., \& Christodoulides, G. (2012). A framework of brand value in B2B markets: The contributing role of functional and emotional components. Industrial Marketing Management, 41, 106-114. http://dx.doi.org/10.1016/j.indmarman.2011.11.009

Leslie, T. W. K., \& McNeill, L. S. (2010). Toward a conceptual model for franchise perceptual equity. Brand Management, 18(1), 21-33. http://dx.doi.org/10.1057/bm.2010.17

Lindgreen, A., Beverland, M. B., \& Farrelly, F. (2010). From strategy to tactics: Building, implementing, and managing brand equity in business markets. Industrial Marketing Management, 39(8), 1223-1225. http://dx.doi.org/10.1016/j.indmarman.2010.02.018

Lynch, J., \& de Chernatony, L. (2004). The power of emotion: brand communication in business-to business markets. Journal of Brand Management, 11(5), 403-419. http://dx.doi.org/10.1057/palgrave.bm.2540185

Mahajan, V., Rao, V., \& Srivastava, R. (1994). An approach to assess the importance of brand equity in acquisition decisions. Journal of Product Innovation Management, 11(3), 221-35. http://dx.doi.org/10.1016/0737-6782(94)90005-1

Mudambi, S., Doyle, P., \& Wong, V. (1997). An exploration of branding in industrial markets. Industrial Marketing Management, 26, 433-446. http://dx.doi.org/10.1016/S0019-8501(96)00151-4

Muniz, A., \& O’Guinn, T. (2001). Brand community. Journal of Consumer Research, 27, 412-432. http://dx.doi.org/10.1086/319618

Nyadzayo, M. W., Matanda, M. J., \& Ewing, M. T. (2011). Brand relationship and brand equity in franchising. Industrial Marketing Management, 40, 1103-1115. http://dx.doi.org/10.1016/j.indmarman.2011.09.004

Park, C. W., Jaworski, B. J., \& MacInnis, D. J. (1986). Strategic Brand Concept-Image Management. Journal of Marketing, 50, 135-145. http://dx.doi.org/10.2307/1251291

Perrigot, R., Basset, G., \& Cliquet, G. (2011). Multi-channel communication: the case of Subway attracting new franchisees in France. International Journal of Retail \& Distribution Management, 39(6), 434-455. http://dx.doi.org/10.1108/09590551111137985

Pitt, L., Napoli, J., \& Van Der Merwe, R. (2003). Managing the franchised brand: The franchisees' perspective. Journal of Brand Management, 10, 411-420. http://dx.doi.org/10.1057/palgrave.bm.2540138

Rao, A., Qu, L., \& Ruekert, R. (1999). Signaling unobservable product quality through a brand ally. Journal of Marketing Research, 36, 258-268. http://dx.doi.org/10.2307/3152097

Simon, C. J., \& Sullivan, M. V. (1993). The measurement of determinants of brand equity: a financial approach. Marketing Science, 12(1), 28-52. http://dx.doi.org/10.1287/mksc.12.1.28

Sirgy, M. J. (1982). Self-Concept in consumer behavior: a critical review. Journal of Consumer Research, 9 , 287-300. http://dx.doi.org/10.1086/208924

Srivastava, R. K., \& Shocker, A. (1991). Brand equity: a perspective on its meaning and measurement. Working Paper, 91-124. Cambridge, MA Marketing Science Institute. http://dx.doi.org/10.1108/00251740010379100

Wood, L. (2000). Brands and brand equity: definition and management. Management Decision, 38(9), 662-669.

Zachary, M. A., McKenny, A. F., Short, J. C., Davis, K. M., \& Wu, D. (2011). Franchise branding: an organizational identity perspective. Journal of the Academy of Marketing Science, 39, 629-645. http://dx.doi.org/10.1007/s11747-011-0252-7

Zaichkowsky, J. L., Parlee, M., \& Hill, J. (2010). Managing industrial brand equity: Developing tangible benefits for intangible assets. Industrial Marketing Management, 39, 776-783. http://dx.doi.org/10.1016/j.indmarman.2010.02.017 